\title{
Small states and international relations pedagogy: Exploring the creative agency frontier
}

Nancy E. Wright*

\section{ABSTRACT}

The world's smallest sovereign states, which in fact comprise the majority of sovereign states worldwide, have a great deal to teach us about different interpretations of power. Much international relations (IR) scholarship has traditionally focused on power as control or coercion; however, power can also mean capability, which is accomplished through what this article identifies as creative agency. Here creative agency is defined as capability according to how one interprets power and the benefits associated with that power. Thus, certain components of power, such as regional or global hegemony, may not be relevant to creative agency; conversely, strong cultural identity or a niche economy may be essential. This article divides small states into three categories: (1) microstates, defined herein as states with populations of fewer than a half million and/or a non-sea area of fewer than 1,000 square kilometers; (2) states with populations of between a half million and one million; and (3) states considered small primarily in relation to their larger neighbors. It uses examples from all these categories to illustrate the phenomenon of creative agency with regard to state formation and type of government and governance. Because the focus of the article is pedagogy, the text includes references to key themes that instructors can introduce with

* Master of Philosophy, Political Science, PhD Candidate, Political Science. Adjunct Professor of Department of Political Science, Pace University, New York, New York (USA). [wrightnancy272@gmail.com]; [https://orcid. org/0000-0001-6074-2530]

Recibido: 3 de diciembre de 2019 / Modificado: 4 de febrero de 2020 / Aceptado: 15 de marzo de 2020

Para citar este artículo:

Wright, Nancy E. (2020). Small states and international relations pedagogy: exploring the creative agency frontier. OASIS, 32, pp. 49-62.

DoI: https://doi.org/10.18601/16577558.n32.05 
small states, as well as to representative works on small states from political science, law, history, and anthropology.

Key words: agency, microstate, power, government, pedagogy

\section{Pequeños Estados y pedagogía de relaciones internacionales: explorando la frontera de la agencia creativa}

\section{RESUMEN}

Los Estados soberanos más pequeños del mundo, que de hecho comprenden la mayoría de los Estados soberanos en todo el mundo, tienen mucho que enseñarnos sobre las diferentes interpretaciones del poder. La gran parte de los estudios de relaciones internacionales (IR) se han centrado tradicionalmente en el poder como control o coerción; sin embargo, el poder también puede significar capacidad, que se logra a través de lo que este artículo identifica como agencia creativa. Aquí, la agencia creativa se define como la capacidad de acuerdo con la forma en que uno interpreta el poder y los beneficios asociados con ese poder. Por lo tanto, ciertos componentes del poder, como la hegemonía regional o global, pueden no ser relevantes para la agencia creativa; por el contrario, una identidad cultural fuerte o una economía de nicho puede ser esencial. Este artículo divide los Estados pequeños en tres categorías: (1) 2 microestados, definidos aquí como Estados con poblaciones de menos de medio millón y/o un área no marítima de menos de 1,000 kilómetros cuadrados; (2)
Estados con poblaciones de entre medio millón y un millón; y (3) Estados considerados pequeños principalmente en relación con sus vecinos más grandes. Utiliza ejemplos de todas estas categorías para ilustrar el fenómeno de la agencia creativa con respecto a la formación del Estado y el tipo de gobierno y gobernanza. Debido a que el enfoque del artículo es la pedagogía, el texto incluye referencias a temas clave que los instructores pueden presentar con Estados pequeños, así como a trabajos representativos sobre Estados pequeños de ciencias políticas, derecho, historia y antropología

Palabras clave: agencia, microestado, poder, gobernanza, pedagogía

\section{INTRODUCTION}

The tendency to associate small sovereign states with vulnerability in world politics stems from the association of power with size and consequently greater resources. ${ }^{*}$ According to this perspective, small states are inevitably objects which are acted upon, without the efficacy to be proactive. This perspective falters, however, in that it limits the definition of power to a capability that enables control or coercion over another and thus depends on military and/or economic resources to do so. This article challenges that perspective on the premise that it fails to account for the many possible interpretations of power that small states may exemplify. Instead of using conventional definitions of power as a point of departure for analysis, it begins by introducing representative scholarship on selected small sovereign states that stresses their use of creative agency, defined here as how one interprets 
power and the benefits associated with that power. The aim of this approach is to suggest themes and works on small states that may be incorporated into international relations (IR) and comparative politics pedagogy, with a view to broadening and diversifying interpretations of power.

*I wish to acknowledge valuable comments received on an earlier draft of this article, prepared for the World International Studies Committee (wISC) Workshop in International Relations, 1-2 October, 2019, in Barranquilla, Colombia, as well as inspiration and much valuable feedback regarding my interest in teaching about small sovereign states from Jacqueline Braveboy-Wagner, Professor of Political Science at City College and The CUNY Graduate Center, The City University of New York; Pamela Chasek, Professor and Chair, Department of Political Science at Manhattan College, and Prof. John Ehrenberg, Professor and Chair Emeritus, Department of Political Science, Long Island University-Brooklyn.

Clearly, concepts of power have already broadened and diversified since the origin of international relations as a discipline, which has been established, albeit with some debate, to be the year 1919 (Achaya and Buzan, 2019). Examples are Joseph Nye's discussions of soft power and smart power (Nye 2011; 2008; 2004) all of which still remain grounded in what has been described as a Western theoretical foundation, as well as scholarship that actually challenges this foundation as failing to represent much of the reality of international relations itself (Achaya and Buzan, 2019; Ling, 2014; Tickner and Blaney, 2013; Tickner and Blaney, 2012; Tickner and Weaver, 2009).
This article divides small states into three categories: (1) states with populations of fewer than a half million and/or a non-sea land area of fewer than 1,000 square kilometers; (2) states with populations of between one half and one million; (3) and states defined as small relative to their larger neighbors. States in the first category, from smallest to largest populations, are: Vatican City, Nauru, Tuvalu, Palau, San Marino, Monaco, Liechtenstein, St. Kitts and Nevis, Marshall Islands, Dominica, Andorra, Antigua and Barbuda, Seychelles, St. Vincent and the Grenadines, Kiribati, Federated States of Micronesia, Tonga, Grenada, St. Lucia, São Tomé and Príncipe, Samoa, Vanuatu, Barbados, Iceland, Bahamas, Belize, Maldives, Malta, and Brunei Darussalam. Those with a population in excess of a half million but a non-sea land area of fewer than 1,000 square kilometers are Singapore and Bahrain. States in the second category are, from lowest to highest population: Cabo Verde, Suriname, Luxembourg, Montenegro, Solomon Islands, Bhutan, Guyana, Cyprus, Comoros, and Fiji. Depending on the subject of analysis, these two categories are often combined under the definition of microstate.

The final category is the most fluid, because size is defined in terms of relativity. Rather than establish a maximum population or area, this category consists of sovereign states that either view themselves or are viewed as small compared to their larger neighbors. For example, Katzenstein's seminal work of the mid-1980s, Small States in World Markets: Industrial Policy in Europe, focused on Sweden, Norway, Denmark, the Netherlands, Belgium, Austria, and Switzerland (Katzenstein, 1985). 
Hey's edited volume, Small States in World Politics: Explaining Foreign Policy Behavior, contains contributions by authors on Paraguay, the English-speaking Caribbean states, Panama, Luxembourg, Austria, The Gambia, Jordan, and Laos (Hey, 2003).

This article presents the world's smallest sovereign states as key examples of creative agency and therefore examples that provide valuable opportunities to discuss and understand different interpretations of power, as well as other key concepts in IR and comparative politics, such as self-determination, sovereignty, government and governance.

The following pages present a brief overview of the history of small states scholarship and IR, drawing largely on Ingebritsen, Neumann, and Gstöhl's edited volume Small States in International Relations (Ingebritsen, Neumann, and Gstöhl, 2006). This is followed by sections on the value of small states in understanding sovereign state formation, using the West European microstates as examples. Next is a discussion of the role of very small states in the persistence of both monarchy and democracy, followed by a concluding statement on the importance of incorporating small states into IR and comparative politics pedagogy in order to recognize and understand a fuller spectrum of interpretations of power and related concepts.

\section{SMALL STATES AND INTERNATIONAL RELATIONS: A BRIEF HISTORICAL OVERVIEW}

In their introduction to Ingebritsen, Neumann and Gstöhl's edited volume, Small States and
International Relations, Neumann and Gstöhl trace the evolution of small state studies as part of IR scholarship (Ingebritsen, Neumann and Gstöhl, 2006). From their overview, one can observe that, much in the same way that endeavors to broaden IR scholarship beyond Western-centric concepts and theories risk the tendency to be reactive, much of the focus on small sovereign states, in the rare times it is salient, is characterized by response and reaction to more conventional IR scholarship that remains centered on defining power in terms of sheer size of area or population, economy, and military might. Small States and International Relations includes key articles and chapters from twentieth century scholarship on small states, which together represent a cross section of themes, most of which nevertheless are reactive in nature, describing and examining small state behavior in contrast to that of their larger counterparts. One exception to this trend is Annette Baker Fox's analysis of small state diplomacy during World War II. Baker Fox examined relations between five strategically situated, relatively small states_-Turkey, Finland, Norway, Sweden, and Spain — and the major belligerent powers of World War II to determine how small states can exercise power in world politics. She concluded that the combination of timing and skill was essential, with small state efficacy grounded in their ability to convince the major belligerent powers that the costs of coercing them would be far greater than the benefits (Baker Fox, 1959).

Baker Fox's work revived an interest in small states in European circles, especially among German-speaking scholars; however, the rise of fascism overshadowed this interest 
in the early twentieth century. Both world wars brought concepts of the state, security, and accompanying theories of realism to the fore, thus continuing to neglect small state studies (Ingebritsen, Neumann and Gstöhl's, 2006, p. 7).

The combination of decolonization and increased interest in the role of international institutions led to a resurgence of small state focus beginning in the 1960s and continuing into the 1980s. The plethora of new states spawned by decolonization prompted concern over potential disruption caused in such organizations as the United Nations General Assembly; at the same time, scholars such as Peter Katzenstein addressed the ways in which small states were coping with the forces of globalization. Thus small states were viewed both as potential challengers to the existing order and as vulnerable entities trying to survive in a world of powerful states and equally powerful non-state agents of the economy (Katzenstein, 1985). Others, such as Krasner, argued that small state efficacy occurred through the consolidation of many Global South states into a bloc which had more agency than individual small states (Krasner 1980).

Writing in the mid-1970s, Höll attributed the resurgence in small state interest as of the 1960s to three sources: (1) the critique, especially in Scandinavia, that political science was biased toward the great powers and overall America-centric; (2) the fundamental social changes toward the end of the 1960 s which signaled a reappraisal of social sciences in general; and (3) increased interdependence throughout the world, which raised issues of how states possessing limited capabilities could cope with the costs of dependence on other states or institutions (Höll 1978: 260). These periods of interest in small state research proved temporal, however; Neumann and Gstöhl attribute this in part to Baehr's conclusion in the mid-1970s that the concept of small states was not useful as an analytical tool to understand the dynamics of world politics (Baehr, 1975; Ingebritsen, Neumann and Gstöhl, 2006). Writing just after the millennium, Knudsen summarized reflection on the past decades of small state research as comprising three rather disconnected trajectories of literature: (1) those concerned with issues of self-determination; (2) those dealing with foreign policy options of neutrality or alliance; and (3) those comparing politics and policy in small states (Knudsen, 2002; Ingebritsen, Neumann and Gstöhl, 2006). More recent theoretical developments in constructivism, including such topics as ideas, norms and global governance, have considerably revived and enhanced small state studies in IR. To date, the field remains young and niche-oriented, but nevertheless with considerable promise for the future, especially in the wake of continuing fragmentation as actors within states struggle for self-determination. The recent creation of South Sudan is just such an example.

The above summary illustrates what was stated in the introduction, namely that, with the possible exception of scholarship emanating from constructivism, the majority of small state research has taken place as a response to mainstream IR scholarship. Such research proceeds from the point of departure that, in the absence of large populations, large economies, and/or large military sectors, small sovereign 
states have no choice but to wrestle with the realities of great power dominance and economic globalization in unconventional ways. While this indeed is often accurate, how they meet these challenges is often overlooked; even more critical, how they define these challenges is also often overlooked.

The role of small sovereign states in regional integration in South America is just such an example, as South American scholar Raul Salgado has recently illustrated (Salgado, 2017). While in some ways his work parallels that of those scholars who have endeavored to explain small state policies in the creation of the European Union, Salgado's work differs, in that, as he explains, while material benefits and instrumental and economic identity are important in both regions, in South America shared culture, norms, rules, and other aspects of collective identity are equally significant. In the absence of competition for material benefits, argues Salgado, small states have a unique opportunity to cooperate around common regional problems and interests. He illustrates his argument with the examples of Ecuador and Uruguay as key actors in the formation of the Union of South American Nations (UNASUR). Categorizing small states as either region-engaging, region-constraining, or region-adapting actors, he places Ecuador and Uruguay in the first category. He explains that Ecuador introduced an amendment into its constitution that stated support for South American integration. Together with Brazil, Ecuador promoted the confirmation of the UNASUR treaty. Similarly, Uruguay introduced a consitutional norm supporting regional integration, which in turn enabled it to help convince Argentina and Brazil to accept certain elements during the discussions that preceded UNASUR's creation (Salgado, 2017).

The following pages address, respectively, themes of state formation and the persistence of both monarchy and democracy in small sovereign states. In doing so, rather than begin with theories, the presentation proceeds more inductively by focusing on scholarship about small states with respect to small state examples that underscore these themes. Instead of providing reactive analyses of existing IR theories, they relate decisions and events that signal unique experiences that can inform without necessarily being conducive to generalization, either to other small states or more universally. To the extent their experience does apply more broadly, they signal the value of learning more about them. To the extent they are anomalies, they signal the need to recognize the great diversity of power defined and applied within IR. Overall, they signal the need to comprehend not only how small states cope with powerful agents around them, but how they actually define power, and how they view themselves as agents of that power.

\section{THE ROOTS OF STATE FORMATION: EXAMPLES FROM THE WEST EUROPEAN MICROSTATES}

Klieger has called the West European microstates "designer nations" (Klieger, 2011). Indeed, the five most commonly identified as such include a buffer (Andorra), a purchase (Liechtenstein), a port semi-enclave (Monaco), a gift (San Marino), and a means to religious autonomy (Vatican City). Although Monaco 
and Vatican City are more well-known than the other three, even these two are rarely discussed as sovereign states.

In 1996 European legal scholar Jorri Duursma published Fragmentation and the International Relations of Micro-states: SelfDetermination and Statehood, about these five West European microstates (Duursma, 1996). She explains in her preface that her inspiration to write the book came from the disintegration and fragmentation of the sovereign states of the Soviet Union, Yugoslavia, and Czechoslovakia. Duursma's analysis traces the origins of sovereign statehood and United Nations membership for these five sovereign states, and in so doing raises the key question of what constitutes legitimacy as a sovereign state. She concludes that size alone is not a determinant. Rather, the essential ingredients for statehood are a defined territory and a population that is attached to that territory over a significant duration. The degree to which an effective government is required varies with the extent to which statehood is challenged from outside (Duursma, 1996).

Nestled between France and Spain in the Pyrenees Mountains, Andorra is Europe's sixth smallest country. Like neighboring Catalonia, Spain, Andorra's official language is Catalan, and it is the only sovereign state in the world to have Catalan as its official language. It is one of only two diarchies in the world - the other being Eswatini-- with administrative powers split between the President of France and Spain's Bishop of Urgell. Charlemagne established Andorra as one of a series of buffer states to prevent Moorish entry into Christian France.
Liechtenstein is one of only two doubly landlocked countries in the world (the other being Uzbekistan). The principality is the outcome of the purchase of two territories, designated the $343^{\text {rd }}$ state of the Holy Roman Empire and achieving sovereignty in 1806. In the words of Klieger,

"Of all the microstates of Europe, Liechtenstein presents the clearest example of the single-minded determination of one family to create a polity free of the constraints of excessive alliances and military deployment, rich in traditional particularisms, graced with direct democracy, dedicated to social welfare, and above all, framed with the recognized right of selfdetermination for all its people" (Klieger, 2011, p. 69).

The next section notes Liechtenstein as an example of an enduring monarchy, a status which seems to contradict Klieger's assertion that the principality is "graced with direct democracy." However, as the next section explains, the personalistic nature of government in very small states suggests that both democracy and monarchy have many connotations, including those that overlap.

Monaco has the distinction of being the most densely populated sovereign state in the world, with over 38,000 people inhabiting about two square kilometers of land. In 1861 Monaco relinquished the territories of Menton and Roquebrune to France in exchange for the latter's recognition of its sovereignty. Today, its total absence of agrarian lands or nature preserves raises the question of whether the tiny principality may be a harbinger of future society, especially in the Global North. Daunting 
as this scenario may be, Monaco is also home to the Oceanographic Institute, and Prince Albert II has consistently expressed commitment to carbon neutrality and marine conservation.

San Marino is distinguished by having the world's oldest uninterrupted -and for many years unwritten-democratic constitution still in operation. Never ruled by a monarch, its origins are somewhat cryptic. Tradition holds that a stonecutter fleeing persecution established the republic with land gifted to him by a noblewoman of Rimini. (Klieger, 2011; Eccardt, 2005).

Of San Marino's collective identity, Klieger writes:

"Being founded as an early Christian community, San Marino existed as a refuge from a hostile pagan Rome. It was a community before Constantine, before the seat of the Empire was moved to Byzantium, and long before the Papacy assumed dominance over Central Italy. This is the foundation of its national identify, and the reason it has insisted for seventeen hundred years that it is not new, nor even has been subject to the Bishop of Rome. That this ideal has prevailed through Sammarinese diplomacy rather than through violence is a testimony that nationalism and warfare are not inevitably paired" (Klieger, 2011).

Finally, returning to Vatican City, the world's smallest sovereign state began with a much larger territory. When Emperor Constantine transferred the imperial capital to Byzantium in 328, Vatican City served as a bulwark for Western Europe, and continued to unite the region during the Early Middle Ages and after the Western Empire collapsed. Centuries later, in 1927 the Lateran Treaty provided for the Holy See's complete independence, compensated in funds for the substantial loss of territory, and swore Vatican City to perpetual neutrality (Klieger, 2011, p. 178).

Of Vatican City Klieger writes:

"At first glance, the State of Vatican City appears as a paradox. A central focus of twenty percent of the world's population is a mere 110 acres of gardens, churches, and palaces — an unlikely place for a country" (Klieger, 2011, p. 159).

Echoing Duursma's previously stated argument that a defined territory and attachment by people to that territory is more important than size itself, Klieger explains that "... the Vatican expresses the central notion that the concept of nationhood is something more than countryside, with cows, pastures, villages, and cities strewn over a certain landscape" (Klieger, 2011, p. 159).

Eccardt summarizes the great paradox between Vatican City's size and the population attached to it in a way that extends the significance of Duursma's aforementioned assertion that both a defined territory and a long-term attachment to that territory are essential:

"Though its territory is the smallest in the world, if all its constituents-Roman Catholics-were counted as its citizens, the Vatican would be the second most populous country on earth" (Eccardt, 2005, p. 299).

With the possible exception of scholarship on relations with the European Union, the West European microstates are rarely addressed in international relations or comparative politics courses. Outside of academia, the West 
European microstates are barely known and where familiar, that knowledge is distorted. For example, more people associate Vatican City with the Pope than with international legal sovereignty. Andorra, Liechtenstein, Monaco, and San Marino are often dismissed as tax havens, destinations for day trips while visiting their larger neighbors, and cloisters of quaintness reminiscent of centuries past. Yet their incorporation affords opportunities for a long view of history that reveals not only survival but prosperity, despite significant losses of territory and substantial periods of impoverishment. The West European microstates have accomplished this largely through skilled diplomacy, flexibility, and pragmatism with respect to ceding territory and/or aspects of sovereignty. Thus their core value for IR and comparative politics scholarship is not how small they are, but the fact that they occupy distinct places in the international system and at various times from their origins to the present have played and continue to play instrumental roles in preservation of empire, setting of norms, mediation, and leadership in international organizations.

\section{Small States and Persistence of Monarchies and Democracies}

In a challenge to Samuel Huntington's seminal argument regarding the longevity of monarchs, Corbett, Veenendaal, and Ugyel present the enduring small monarchies of Bhutan, Liechtenstein, and Tonga (Corbett, Veenendaal, and Ugyel, 2016 ). Huntington contended that modern monarchs confronted the ironic dilemma of needing to centralize power in or- der to promote development; yet such social, cultural, and economic reforms to this end yield new elites who threaten monarchical authority. The antidote to this, of course, is to postpone such reforms; however, such complete adherence to traditionalism carries the risk of revolt by the populace. Thus, according to Huntington, a peaceful transition from an absolute monarchy to a constitutional monarchy, democratic republic, or other electoral system is impossible.

While Corbett, Veenendaal and Ugyel acknowledge the validity of Huntington's "King's Dilemma" argument, they challenge him on the premise that it does not explain the last remaining monarchies that have persisted through waves of democratization. For the approximately 20 absolute or semi-absolute monarchies currently in the world, most of which are located on the Arabian Peninsula, the authors attribute their durability to an inherent conservatism and institutional loyalty that can best be explained by:

(1) their reluctance to risk instability in the wake of their vulnerable positions in the international system, and (2) a familiarity among citizens that discourages both pluralistic political participation and dissent. Accordingly, in small states, power is more likely to be concentrated in individuals more than in legal institutions; in other words, power is personalized (Corbett, Veenendaal, and Ugyel, 2016).

The authors illustrate their counter-argument to Huntington with the examples of Tonga, Bhutan, and Liechtenstein, each of which reinforced monarchy with different processes. Tonga's late King Toupu elected to cede power to the legislative assembly. Bhu- 
tan's King Jigme Singye Wangchuck promoted democratic reform and in doing so, met opposition from the majority of Bhutanese, who revered him and collectively lamented the transition. In Liechtenstein the opposite occurred; Prince Hans-Adam II justified increasing his own power relative to the principality's democratic institutions by optimizing citizens' disillusionment with elected representatives. In each of these three cases, as well as in the majority of the approximately 20 absolute or semi-absolute monarchies of the world--small populations are critical to the institutional fidelity and personal loyalty deemed responsible for the monarchy's longevity.

The personalistic politics that the authors describe in their study of small state monarchies plays an equally fundamental role in democratic longevity in small states. In their comparative study of democratization in 39 small sovereign states, Corbett and Veenendaal explain their primary reason for undertaking such a study:

"We know that small states are more likely than large ones to score well in Freedom House rankings. But, aside from Freedom House, the other major democracy datasets_-Polity IV and the Economist's Democracy Index-exclude many of them. As a result, virtually all scholars in the field of comparative politics and democratization have overlooked these cases and so almost everything that we think we know about democratic transition and consolidation suffers from an unstated gigantism" (Corbett and Veenendaal, 2018, p. 11).

Using established theories of democratization as their point of departure, their key questions are, "Why are small states more democratic than larger ones?", and "How does domestic politics actually work in small states?" (Corbett and Veenendaal, 2018, pp. 13-15). They conclude that, on the one hand, as is the case with small state monarchies, personalistic politics in small states leads to greater proximity and accessibility between leaders and citizens, and thus to a natural transparency. On the other hand:

"Small is easy to dominate; it heightens enmities; stifles pluralism and dissent; it creates capacity deficits; it undermines ideological representation, blurs the distinction between public and private resulting in heightened suspicion of corruption, and strongly increases the tendency toward clientelism, patronage, nepotism, and other forms of particularism. This leads us back towards the American republican tradition and the corresponding argument that 'bigness' is better for modern representative democracies" (Corbett and Veenendaal, 2018, p. 255).

Two of the sovereign states included in Corbett and Veenendaal's study are the former Portuguese colonies of Cabo Verde and São Tomé and Príncipe. Both are examples of unlikely democracies, according to conventional theories of democratization, and of places that have been largely ignored in IR and comparative politics scholarship, despite their key roles in the formation of empire, the slave trade, and struggles for independence. Lobban describes Cabo Verde as pivotal in Portugal's golden age of discovery, the provision of coal and fuel for the British empire, and in the slave trade. Lobban also attributes Cabo Verde's longevity of democratic stability to the inclusion of oppo- 
sition political parties soon after independence (Lobban, 1995).

Turning to São Tomé and Príncipe, upon gaining independence, the two-island archipelago became a socialist one-party state. The departure upon independence of most Portuguese inhabitants, who had occupied the majority of administrative positions, left a vacuum of adequately trained personnel, resulting in economic decline. This prompted the socialist republic in 1990 to introduce multiparty democracy and a market economy. Despite multiple changes in government and persistent economic decline, São Tomé and Príncipe remains one of Africa's most stable and enduring democracies, thus challenging conventional associations of stable governments and economies as necessary to longterm democratization (Seibert, 2016).

Yet another example_-and in many ways an exception - is the Caribbean island of Dominica. Among former British island colonies of the Caribbean, Dominica has the distinction of being the only former colony to establish itself as a republic very soon after gaining independence from Britain. Historian and anthropologist Lennox Honychurch has chronicled in comprehensive detail Dominica's history, highlighting in particular the pivotal role of the island's Maroons in not only withstanding the military forces of their colonizers, but also in creating a free and independent society (Honychurch, 2017). Dominica was the last island in the Caribbean to be colonized; the Kalinago, Dominica's indigenous people, had long found sanctuary in the island's extremely rugged mountainous terrain. Most Maroon chiefs had been born in
Africa and thus knew of possibilities beyond the plantation society. Dominica was the only Commonwealth Caribbean country to evolve directly into independence as a republic; Trinidad and Guyana became republics a number of years following their independence. To date, Dominica is the only member of the Organization of Eastern Caribbean States (OECS) for which the head of state is elected from within rather than serving in the role of a governor-general.

Dominica's autonomous path has deep historical roots. On March 31, 1660, the Treaty of St. Christopher between the English and the French declared Dominica as well as St. Vincent as neutral, not to be occupied by any European power, but to remain with the Kalinago people indefinitely. The Treaty exemplified philosophies of the noble savage perpetuated by Jean-Jacques Rousseau and others of the European Enlightenment. Two other major reasons were to prevent a surplus of sugar cane and consequent declining revenues, and also to establish a buffer for the neighboring sugar colonies (Honychurch 2017: 25-26). Although none of these reasons supported true Dominican independence, the neutral status benefited the Maroons with a century to establish a strong base on Dominica, thus distinguishing the island from its colonized neighbors.

Honychurch stresses that the weakness of the colony from the outside served to strengthen the role of the Maroons from within. Maroons and Kalinagos together farmed the rugged terrain effectively. This, combined with information about the French Revolution and the founding of Haiti, the world's first black- 
led republic and the first independent Caribbean state, sustained the Maroons through decades of bloodshed as the British intensified their grip on the island until it finally achieved independence in 1978 (Honychurch, 2017, pp. 155-159).

The narrative of Dominica's history from the pre-colonial era to the present is valuable not only to understand the unique history of the island itself, but also to consider and possibly re-appraise what may or may not be preconditions for a stable republic. The Maroons clearly played a key role not only in resisting colonial domination, but also in their conviction that a viable independent republic was possible. Furthermore, they believed this, because they had experienced economic and social self-sufficiency in Africa, and thus had a template on which to build their society. At the same time, the combination of the island's rugged inaccessibility and the British and French neutrality designation for a century protected the Maroons from both invasion and external influences that may have otherwise weakened their resolve. The unique scenario of Dominica's colonial era cautions against over-generalizing small island states as weak or dependent. In other words, Dominica, like many small sovereign states, should be regarded as a subject or agent, not as an object of a world of powerful states and non-state actors. Whatever its vulnerabilities, its decisions and actions are its own. Dominica's example, like the examples of the Western European microstates, also illustrates the need to examine the internal dynamics of small states over long periods. This area of study has been particularly neglected, since very small states are frequently collectively marginalized in scholarship, rather than analyzed individually and from within.

Excluding or marginalizing small states from research on the conditions for monarchy, democracy, or any type of government or governance limits interpretations of those concepts themselves, and thus distorts understanding of what is necessary to make democracy viable over time.

\section{SUMMARY AND CONCLUSIONS}

One reason small states have too often been neglected in IR and comparative politics scholarship is that when one conducts analysis from a point of departure of established theories of power, government, and governance, the world's smallest states immediately appear inconsequential. If they do gain attention, it is in the form of objects upon which their larger counterparts act. If, however, one begins with a focus on the histories of these states themselves, creative agency readily emerges as a driving force to ensure that the small state not only survives, but thrives in the world. This creative agency is the capability to define and exercise power on one's own terms, such that even in the wake of economic, military, or political dependence on larger neighbors, small states can distinguish themselves through what they may offer through diplomacy, niche economies, key resources, or as catalysts for regional and international cooperation and integration, as well as through culture and an enduring attachment to the territory they have established as their own through international law.

Furthermore, small states have proven their capacity to sustain both monarchy and 
democracy, a phenomenon that suggests more autonomy than is usually recognized in IR and comparative politics scholarship. As those who have examined this trend so aptly document, the key to understanding this type of longevity is to recognize and understand that the processes and major components of both monarchy and democracy often differ for small states, especially in their focus on loyalty and personalistic politics. Thus, what keeps small states monarchical or democratic does not necessarily transfer to their larger counterparts. Similarly, Dominica's experience of Maroon societies does not completely resemble either the experience of other small Caribbean states or of Maroon societies in larger states. Rather, the experiences of the world's smallest states in preserving and exercising forms of government and governance, sovereignty, and autonomy underscore the tremendous diversity of IR, of comparative politics and of foreign policy. The inclusion of this direction of analysis and discourse in IR and comparative politics pedagogy is vital to recognizing and comprehending the range and complexity of power when applying existing IR theories, as well as expanding upon them and developing new concepts and theories that are congruent with the world's changing dynamics.

\section{REFERENCES}

Baehr, P.R. (1975). Small States: A Tool for Analysis? World Politics 27 (3): 456-466.

Baker Fox, A. (1959). The Power of Small States: Diplomacy in World War II. Chicago: University of Chicago Press.
Corbett, J. and Veenendaal, W. (2018). Democracy in Small States: Persisting Against All Odds. Oxford, United Kingdom: Oxford University Press.

Corbett, J.; Veenendaal, W. and Ugyel, L. (2016). Why Monarchy Persists in Small States: The Cases of Tonga, Bhutan, and Liechtenstein, Democratization, August.

Duursma, J. C. (1996). Fragmentation and the International Relations of Micro-states: Self-Determination and Statehood. Cambridge: Cambridge University Press.

Eccardt, T. (2005). Secrets of the Seven Smallest States of Europe. New York: Hippocrene Books.

Hey, J. A. K. (ed.) (2003). Small States in World Politics: Explaining Foreign Policy Behavior. New York: Lynne Rienner.

Höll, O. ed. (1983). Small States in Europe and Dependence. Boulder, co: Westview Press.

Honychurch, L. (2017). In the Forests of Freedom: The Fighting Maroons of Dominica. London, UK and Trafalgar, Dominica: Papillotte Press.

Ingebritsen, C.; Neumann, I, and Gstöhl, S. (eds.) (2006). Small States in International Relations. Seattle and Reykjavik: University of Washington and University of Iceland.

Katzenstein, P. J. (1985). Small States in World Markets: Industrial Policy in Europe. Ithaca, NY: Cornell University Press.

Klieger, P. C. (2011). The Microstates of Europe: Designer Nations in a Post-Modern World. Lanham, MD: Lexington Books.

Knudsen, O. F. (2002). Small States, Latent and Extant: Towards a General Perspective. Journal of International Politics and Development 5: 2.

Krasner S. (1981). Transforming International Regimes: What the Third World Wants and Why. International Studies Quarterly 25 (1): 119-148. 
Ling, L.H.M. (2014). Imagining World Politics: Sihar and Shenya, a Fable for Our Times. London and New York: Routledge.

Lobban, R. A., Jr. (1995). Cape Verde: Crioulo Colony to Independent Nation. New York: Taylor and Francis.

Nye, J. S., Jr. (2011). The Future of Power. New York: Public Affairs/ Pearson.

Nye, J. S., Jr. (2004). Power in the Global Information Age: From Realism to Globalization. New York: Routledge.

Nye, J. S., Jr. (2008). The Powers to Lead. London and New York: Oxford University Press.

Nye, J. S., Jr. (2004). Soft Power: The Means to Success in World Politics. New York: Public Affairs/Pearson.
Salgado, R. (2017). Small Builds Big: How Ecuador and Uruguay Contributed to the Construction of UNASUR. Quito, Ecuador: FLACSO Ecuador.

Seibert, G. (2016). São Tomé and Príncipe 1975-2015: Politics and Economy in a Former Plantation Colony. Estudos Ibero-Americanos, Porto Alegre, 42 (3): 987-102.

Tickner, A. and D. L. Blaney (eds.) (2013). Claiming the International. New York: Routledge.

Tickner, A. and D. Blaney (eds.) (2012). Thinking International Relations Differently. London and New York: Routledge.

Tickner, A. and O. Weaver (eds.) (2009). International Relations Scholarship Around the World. London and New York: Routledge. 